\title{
RELEVANSI PENDIDIKAN AGAMA ISLAM TERINTEGRASI DALAM MEMBANGUN KARAKTER BANGSA DI ERA DIGITAL 4.0
}

\author{
Ahmad Rifa'i \\ ASN Kemenag Jakarta Pusat \\ rifai210678@gmail.com \\ Ifham Choli \\ ifhamcholi@yahoo.co.id
}

Dosen FAI UIA

\begin{abstract}
Islamic religious education is one of the main components in shaping the character and personality of the nation. In this digital era 4.0 where particular communication has become universal, Islamic religious education must be able to become a spirit that directs technology so that it is always useful in human life. This study aims to find ways to integrate Islamic religious education with science and technology that can improve the character building of the nation. The research methodology used in this study is a qualitative descriptive research method that describes the current conditions of Islamic religious education learning and its relation to the nation's character building. The result of this research is that Islamic religious education should not be monolithic but must be integrated with non-religious subjects as well as science and technology so that today's young generation are willing and interested in studying religion well and Islamic religious education can be of value. which colors every skill and profession of Indonesian citizens, so that the morals and morals of the nation develop well according to the example of the Prophet Muhammad and aspired to by the state.
\end{abstract}

Keyword : Islamic Religious Education, Character Building

\begin{abstract}
ABSTRAK
Pendidikan Agama Islam adalah salah satu komponen utama dalam membentuk karakter dan kepribadian bangsa. Di era digital 4.0 ini dimana komunikasi yang asalnya partikular menjadi universal, pendidikan agama Islam harus dapat menjadi ruh yang mengarahkan teknologi agar senantiasa bermanfaat dalam kehidupan manusia. Penelitian ini bertujuan untuk menemukan cara mengintegrasikan pendidikan agama
\end{abstract}


Islam dengan sains dan teknologi yang dapat meningkatkan pembentukan karakter bangsa. Metodologi penelitian yang digunakan dalam penelitian ini adalah metode penelitian deskriptif kualitatif yang menggambarkan tentang kondisi pembelajaran pendidikan agama Islam saat ini serta kaitannya dengan pembangunan karaakter bangsa. Hasil dari penelitian ini adalah pendidikan Agama Islam tidak boleh bersifat monolitik namun harus integratif dengan mata pelajaran non agama serta sains dan teknologi agar generasi muda saat ini mau dan tertarik untuk mempelajari agama dengan baik dan juga pendidikan agama Islam dapat menjadi nilai yang mewarnai setiap keahlian dan profesi warga negara Indonesia, sehingga dengan demikian akhlak dan karakter bangsa akan terbangun dengan baik sesuai dengan yang dicontohkan Nabi Muhammad Saw dan dicita-citakan oleh undang-undang.

\section{Kata Kunci : Pendidikan Agama Islam, Pembangunan Karakter}

\section{PENDAHULUAN}

Era Digital 4.0 atau sering juga disebut sebagai Era Revolusi Industri 4.0 adalah istilah yang digunakan untuk memulai era revolusi industri yang keempat. Ravolusi industri ini telah terjadi empat kali. Pertama terjadi pada tahun 1784 yang ditandai dengan ditemukannya mesin uap oleh James What, yang menggantikan pekerjaan tenaga manusia disemua bidang isdustri. Lalu berlanjut pada abad ke 19, dengan digunakannya tenaga listrik pada semua sektor industri. Revolusi ketiga terjadi pada tahun 1970 dengan digunakannya komputerisasi dan manufaktur pada bidang isdustri. Dan saat ini dunia sedang memasuki era revolusi industri yang keempat, dengan digunakannya interkoneksi, analisis data, teknologi sensor yang diintegrasikan menjadi satu untuk mengembangkan dunia industri.

Pada era industri 4.0, teknologi manufaktur sudah masuk pada tren otomatisasi dan pertukaran data. Hal itu mencakup sistem cyber-fisik, internet of things (IoT), komputasi awan, dan komputasi kognitif.

Kemajuan ini telah mengubah banyak bidang kehidupan manusia, termasuk ekonomi, dunia kerja, bahkan gaya hidup manusia itu sendiri. Singkatnya, revolusi 4.0 menanamkan teknologi cerdas yang dapat terhubung dengan berbagai bidang kehidupan manusia. Jika dunia pendidikan tidak berbenah maka hasil out put dari pendidikan tidak akan mampu berkiprah maksimal dalam menghadapi lesatan revolusi industri ini. 
Dalam dunia pendidikan Islam, kepekaan terhadap revolusi ini masih belum terasa. Sumber daya yang bermutu rendah didukung dengan kurang kreatifnya para pendidik dalam menyampaikan pendidikan Islam ini, maka posisi strategis pendidikan agama Islam sebagai kontrol bagi kemajuan teknologi ini agar tidak liar menjadi hilang. Kuat arus informasi digital malah justru sering menyeret para pendidik ke dalam ujaran kebencian dan penyebaran informasi dusta.

Materi pendidikan agama Islam yang disajikan di sekolah masih banyak terjadi pengulangan-pengulangan dengan tingkat sebelumnya. Disamping itu, materi pendidikan agama Islam dipelajari tersendiri dan lepas kaitannya dengan bidang-bidang studi lainnya, sehingga mata pelajaran agama Islam tidak diterima sebagai sesuatu yang hidup dan responsif dengan kebutuhan siswa dan tantangan perubahan. Bahkan kehadiran pelajaran pendidikan agama Islam dapat dipastikan akan membosankan dan kurang menantang. Metodologi pembelajaran agama Islam di sekolah disampaikan sebagian guru secara statis-indoktrinatif-doktriner dengan fokus utama kognitif yang sibuk mengajarkan pengetahuan dan peraturan agama, akan tetapi bagaimana menjadi manusia yang baik: penuh kasih sayang, menghormati sesama, peduli pada lingkungan, membenci kemunafikan dan kebohongan dan sebagainya justru luput dari perhatian.

Merespon berbagai hal tentang mata pelajaran PAI tersebut, dapat diidentifikasi bahwa rendahnya kualitas PAI di sekolah karena beberapa faktor. Pertama, factor materi PAI itu sendiri yang lebih banyak berorientasi pada tafakuh fidin sehingga cenderung bersifat indoktrinasi tidak seperti materi pelajaran lainnya yang langsung bersentuhan dengan dunia kerja. Kedua, metode pembelajaran PAI cenderung di dominasi ceramah dan hafalan. Ketiga, PAI tidak diujikan dalam ujian nasional. Keempat,keterbatasan sarana pembelajaran PAI. Kelima, PAI merupakan salah satu materi pelajaran yang lebih dekat dengan kehidupan di keluarga dan masyarakat (Sunhaji, 2014:334). Pembentukan karakter bangsa sangat bergantung dengan keberhasilan pembelajaran agama Islam yang terintegrasi ini, lebih-lebih di era revolusi industri 4.0 yang ditandai dengan melesatnya teknologi informasi ini PAI harus berinteraksi positif dengan kemajuan teknologi namun juga menjadi filter bagi dampak buruk teknologi itu sendiri. Sehingga agama akan menjadi ruh yang menjiwai berbagai macam profesi yang ada dinegeri ini.

\section{KAJIAN PUSTAKA}

\section{A. Makna Karakter Dalam Perspektif Islam}


Karakter secara bahasa berasal dari bahasa latin charakter, yang antara lain berarti: watak, tabiat, sifat-sifat kejiwaan, budi pekerti, kepribadian atau akhlak. Menurut ahli psikologi, karakter adalah sebuah sistem keyakinan dan kebiasaan yang mengarahkan tindakan seorang individu. Simon Philips memberikan definisi karakter yaitu kumpulan tata nilai yang menuju pada suatu sistem, yang melandasi pemikiran, sikap, dan perilaku yang ditampilkan.( Reflekasi Karakter Bangsa (2008:235))

Menurut Imam Ghozali yaitu salah satu ahli filsafat islam menganggap bahwa karakter lebih dekat dengan akhlaq, yaitu spontanitas manusia dalam bersikap, atau melakukan perbuatan yang telah menyatu dalam diri manusia sehingga ketika muncul tidak perlu dipikirkan lagi

Dari beberapa pengertian karakter di atas dapat disimpulkan bahwa karakter adalah kumpulan sistem tabiat, watak, dan akhlak yang lahir dari kebiasaan hidup . Dalam mekanismenya, ada 3 unsur yang membentuk karakter manusia yaitu pada saat kecil, lingkungan dan keilmuan.

Dari 3 unsur tersebut, unsur pertama dan kedualah yang memilik peran banyak dalam pembentukan karakter manusia. Dalam perspektif Islam, karakter atau akhlak mulia merupakan buah yang dihasilkan dari proses penerapan syari'ah (ibadah dan muamalah) yang dilandasi oleh fondasi aqidah yang kokoh. Ibarat bangunan, karakter atau akhlak merupakan kesempurnaan dari bangunan tersebut setelah fondasi bangunannya kuat (Marzuki.tth:5 ).

Karakter Islami adalah karakter yang berlandaskan agama islam, yaitu serangkaian perilaku normatif manusia, baik sebagai makhluk individu maupun makhluk sosial, yang normanya di turunkan dari ajaran dari ajaran islam, yang bersumber dari Al Quran, dan As Sunnah \{Kepribadian dalam Psikologi Islam (2006:14) Dr. H. Abdul Mujib, M. Ag \}.

Seorang Muslim yang memiliki aqidah atau iman yang benar pasti akan terwujud pada sikap dan perilaku dalam kehidupan sehari-hari yang didasari oleh imannya, maka akan terwujud dalam pribadi muslim sebuah karakter yang islami apabila memiliki aspek tersebut. 
Contoh dari karakter islam sendiri yaitu, seperti apa yang dicontohkan Rasul kita nabi Muhammad (Sollu 'alaihi) sebagaimana dalil pada surat Al-Ahzab ayat 21 yang berbunyi :

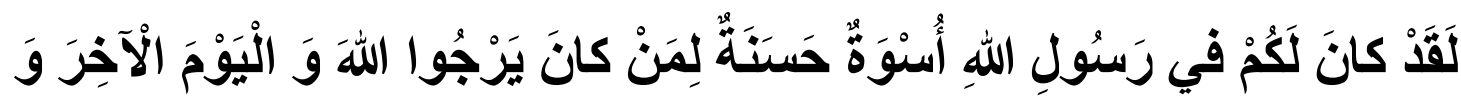 ذَكَرَ اللهَ كَثْيراً}

Sesungguhnya adalah bagi kamu pada Rasulullah itu teladan yang baik; Bagi barangsiapa yang mengharapkan Allah dan Hari Kemudian dan yang banyak ingat kepada Allah. ( Ayat 21)

Oleh karena itu, karakter itu harus memadukan aspek kognitif, afektif dan psikomotorik. Rasulullah SAW sudah memberikan teladan itu dengan membangun pendidikan berbasis moral dan etik sebagaimana yang difirmankan Allah pada surat AlAhzab ayat 21.

\section{B. Arti Pendidikan Agama Islam dan Tujuannya}

Pendidikan dapat diartikan secara sempit yaitu bimbingan yang diberikan kepada anak-anak dampai ia dewasa._Sedangkan dalam arti luas adalah segala sesuatu yang menyangkut proses perkembangan dan pengembangan manusia, yaitu upaya menanamkan dan mengembangkan nilai-nilai bagi anak didik, sehingga nilai-nilai yang terkandung dalam pendidikan itu menjadi bagian dari kepribadian anak yang pandai, baik, mampu hidup, berguna bagi masyarakat.

Menurut Ki Hajar Dewantara pendidikan adalah suatu usaha yang dilakukan dengan penuh keinsyafan yang ditujukan untuk keselamatan dan kebahagian manusia.

Pendidikan Agama Islam adalah sebagai bimbingan terhadap pertumbuhan rohani dan jasmani menurut ajaran Agama Islam dengan hikmah mengarahkan, mengajarkan, melatih, mengasuh, dan mengawasi berlakunya semua ajaran agama Islam.

Istilah membimbing, mengarahkan dan mengasuh serta mengajarkan dan melatih, mengandung pengertian usaha mempengaruhi jiwa anak didik melalui proses setingkat demi setingkat menuju tujuan yang ditetapkan, yaitu menanamkan takwa dan 
akhlak serta menegakkan kebenaran, sehingga terbentuklah manusia yang berpribadi dan berbudi luhur.

Dari definisi di atas ada tiga poin yang dapat disimpulkan yaitu:

Pertama, Pendidikan Agama Islam menyangkut aspek jasmani dan rohani, karena keduanya merupakan satu kesatuan yang tidak bisa dipisahkan, oleh karena itu pembinaan terhadap keduanya harus seimbang.

Kedua, Pendidikan Agama Islam mendasarkan konsepsinya pada nilai-nilai religius. Ini berarti bahwa pendidikan Agama Islam tidak mengabaikan faktor teologis sebagai sumber dari ilmu itu sendiri. sebagaimana firman Allah Swt dalam Q.S. AlBaqarah:31.

Ketiga, adanya unsur takwa sebagai tujuan yang harus dicapai, sebagaimana kita ketahui bahwa takwa merupakan benteng yang dapat berfungsi sebagai daya tangkal terhadap pengaruh-pengaruh negatif yang datang dari luar.

Berdasarkan pengertian di atas dapat disimpulkan bahwa pendidikan Islam adalah bimbingan yang diberikan oleh seseorang agar ia berkembang secara maksimal sesuai dengan ajaran Islam.

\section{METODOLOGI PENELITIAN}

Metode penelitian yang digunakan dalam penelitian ini adalah metode penelitian deskriptif kualitatif. Sumber data dalam penelitian ini adalah:

1. Sumber data primer, berupa jurnal, buku, majalah ataupun Koran yang berkaitan dengan penelitian.

2. Sumber data sekunder, berupa pengamatan dan wawancara terhadap guru dan siswa.

Analisis data yang digunakan dalam penelitian ini termasuk dalam ragam analisis kualitatif yang bertujuan untuk memahami suatu situasi, peristiwa, peran, interaksi dan kelompok. Peneliti berusaha untuk obyektif dan jujur dalam melakukan telaah data.

\section{HASIL PENELITIAN}

\section{A. Integrasi Pendidikan Agama Islam Dengan Sains Dan Teknologi di Era Digital 4.0}


Pembelajaran pendidikan agama Islam saat ini masih bersifat monolitik artinya berdiri sendiri bukan bersifat integratif. Kalau dicermati dengan baik dan seksama pada hakekatnya pembelajaran Biologi, Fisika dan Kimia merupakan aplikasi dari pendidikan Agama Islam. bahkan teori-teori sains sudah ada sejak dahulu dalam Al Qur'an (Sunhaji, 2014:336).

Pernyataan senada telah dinyatakan oleh Soedjatmoko (1996:2), bahwa pendidikan agama harus berusaha berintegrasi dan ber-sinkronisasi dengan pendidikan non-agama. Pendidikan agama tidak boleh dan tidak dapat berjalan sendiri, tetapi harus sinergi dengan program-program pendidikan non-agama agar mempunyai relevansi terhadap perubahan sosial yang terjadi di masyarakat, tanpa sinergi dengan mata pelajaran lain seperti sains, pengetahuan peserta didik hanya terbatas pada aspek nilainilai keagamaan saja.

Merujuk kepada sejarah Islam, teknologi bukanlah sesuatu yang asing. Teknologi akan terus berkembang sejalan dengan kepandaian manusia untuk memudahkan urusan kehidupan. Islam tidak pernah menghalangi atau bahkan mengharamkan teknologi terutama dimanfaatkan untuk pendidikan. Tidak ada hukum sesuatu itu haram kecuali terdapat nas dan dalil terang menyatakan sesuatu itu haram.

Wacana perpaduan antara sains dan Agama di Indonesia sudah lama digaungkan sebagaimana yang tertuang dalam UUSPN Nomor 20 Tahun 2003 pasal 30 yang mewajibkan penyelenggaraan pendidikan Agama pada semua strata pendidikan sebagai bentuk kesadaran bersama untuk mencapai kualitas hidup yang utuh.

Peserta didik saat ini sangat kritis dan tidak begitu saja menerima pelajaran pendidikan agama Islam. Ketika disampaikan tentang haramnya makanan tertentu maka mereka tidak serta merta menerima namun mereka mempertanyakan tentang keharaman makanan tersebut. Dalam kasus seperti inilah peran sains diharapkan mampu memberikan penjelasan secara menyeluruh. Sehingga antara pendidikan agama Islam dan sains dapat saling mendukung dalam memberikan pemahaman yang utuh kepada peserta didik.

Integrasi sinergis antara Agama dan ilmu pengetahuan secara konsisten akan menghasilkan sumber daya yang handal dalam mengaplikasikan ilmu yang dimiliki dengan diperkuat oleh spiritualitas yang kokoh dalam menghadapi kehidupan. Islam 
tidak lagi dianggap sebagai Agama yang kolot, melaikan sebuah kebutuhan untuk mengaktualisasikan diri di berbagai bidang kehidupan, dan sebagai fasilitas untuk perkembangan ilmu dan teknologi (Turmudi, 2016: 15).

Pengintegrasian pendidikan Agama Islam dengan sains dan teknologi bisa dimulai dari metode pembelajaran agama Islam. Pada pembelajaran PAI terdapat pokok bahasan yang memiliki keterkaitan dan sinergi dengan materi pelajaran Fisika tersebut, misalnya tentang perlunya ukuran yang tepat dalam penimbangan zakat, ukuran nishab zakat dan sebagainya sebagaimana dalam al-Qur'an surat al-Qomar ayat 49 (sesungguhnya kami menciptakan segala sesuatu menurut ukuran), dan dalam surat alFurqan ayat 2 (Dia telah menciptakan segala sesuatu dan menetapkan ukuranukurannya dengan serapi-rapinya). Demikian juga dalam ilmu Biologi tentang makhluk hidup dijelaskan uraian tentang proses kejadian manusia, mulai dari proses bertemunya sel telur (ovum) dengan spermatozon, kemudian menjadi darah, lalu menjadi daging, kemudian menjadi tulang sampai janin. Demikian juga tentang binatang dan tumbuhan (flora dan fauna). Dalam pembelajaran PAI juga terdapat pokok bahasan tentang proses kejadian manusia, binatang dan tumbuhan, mulai dari janin sampai dewasa. Dalam alQur'an (surat al-Fathir ayat27 dan 28), tentang tumbuh-tumbuhan dan binatang, kemudian (QS.al-Mu'minun ayat 12 -14), tentang proses kejadian manusia dari sejak spermatozon sampai menjadi janin (QS. al-Mu'minun ayat 18-22) tentang perkembangan makhluk hidup. Dari contoh tersebut, maka pengintegrasian sains dalam pelaksanaan pembelajaran PAI, diharapkan dapat memberikan kontribusi yang positif terutama pemahaman siswa terhadap PAI lebih integral serta diharapkan dapat meningkatperilaku kesalehannya.

Model pembelajaran tematik-integratif ini sangat membantu memfasilitasi proses belajar-mengajar peserta didik, karena masalah yang dihadapi di dunia nyata tidak selamanya dapat dijelaskan secara ter-kotak-kotak ke dalam bidang studi atau mata pelajaran, melainkan terdapat saling kaitan antar bidang studi/mata pelajaran. Pemanfaatan teknologi juga menjadikan peseta didik lebih tertarik untuk mengenal Islam dengan baik. Pembuatan media ajar dalam bentuk animasi ataupun video-video pendek lebih dapat diterima oleh generasi digital ini dibanding dengan mendengarkan ceramah. Kreatifitas pendidik dalam mengemas ajaran Islam dalam bentuk aplikasi juga 
dapat menambah minat belajar remaja saat ini, misalnya plikasi zakat, warist maupun astronomi atau falak.

\section{B. Peran Pendidikan Agama Islam Dalam Membentuk Karakter Bangsa}

Pembinaan kepribadian/karakter atau jiwa utuh hanya mungkin dibentuk melalui pengaruh lingkungan khususnya pendidikan. Sasaran yang ditempuh atau dituju dalam pembentukan kepribadian/karakter ini adalah kepribadian yang memiliki akhlak yang mulia dan tingkat kemulian akhlak erat kaitannya dengan tingkat keimanan.

Dalam pembentukan karakter seseorang, hendaknya setiap guru menyadari bahwa dalam pembentukan karakter sangat diperlukan pembinaan dan latihan-latihan akhlak pada siswa, bukan hanya diajarkan secara teoritis, tetapi harus diajarkan ke arah kehidupan praktis. Agama sebagai unsur esensi dalam kepribadian manusia dapat memberi peranan positif dalam perjalanan kehidupan manusia, selain kebenarannya masih dapat diyakini secara mutlak.

Dalam hal pembentukan karakter seseorang, pendidikan agama mempunyai peranan yang sangat penting dalam kehidupan. Pendidikan agama berperan sebagai pengendali tingkah laku atau perbuatan yang terlahir dari sebuah keinginan yang berdasarkan emosi. Jika ajaran agama sudah terbiasa dijadikannya sebagai pedoman dalam kehidupan seseorang sehari-hari dan sudah ditanamkannya sejak kecil, maka tingkah lakunya akan lebih terkendali dalam menghadapi segala keinginankeinginannya yang timbul.

Telah kita ketahui banyak anak-anak memiliki kepribadian buruk yang mengakibatkan merosotnya moral. Betapa pentingnya pendidikan agama untuk seseorang, dan betapa pula besarnya bahaya yang terjadi akibat kurangnya pendidikan agama itu. Untuk itu, perlu kiranya kita mencari jalan yang dapat mengantar kita kepada terjaminnya kepribadian yang dapat menciptakan dan memelihara ketentraman dan kebahagiaan masyarakat dan bangsa di kemudian hari.

Maka dari itu untuk membentuk karakter yang berlandaskan agama pertamatama di tentukan oleh keluarga terlebih dahulu, karena keluarga memiliki peran penting dalam mendidik agama bagi anak-anaknya, terutama dalam pembentukan kepribadian atau karakter. Artinya keluarga berkewajiban memperkenalkan dan mengajak anak serta anggota keluarga lain kepada kehidupan beragama sedini mungkin 
Agama banyak memberikan pengajaran yang baik dalam membentuk kepribadian seseorang, contohnya seorang anak akan bersikap santun terhadap orang yang lebih tua di bandingkan dia, itu karena orang tua sudah mengajarkaan kebaikan sejak dini kepada anaknya, jadi si anak tidak akan mengubah karakter dia menjadi orang lain. Karena itu sudah menjadi syariat dalam beragama. Agama banyak memberikan kita ulasan mengenai pembentukan karakter yang lebih baik.

Jadi, ilmu pendidikan mempunyai hubungan yang erat dengan Agama, Sehingga Agama dijadikan sebagai suatu landasan perumusan pendidikan, dan pendidikan agama mempunyai pengaruh besar dalam pembentukan moral dan karakter anak didik. Oleh karena itu orang tua/pendidik haruslah memperhatikan hal-hal sebagai berikut :

a) Pendidikan agama hendaklah diberikan kepada anak sedini mungkin, ajarilah dari hal-hal yang kecil sesuai dengan tuntunan agama.

b) Pelajaran pendidikan agama bukan merupakan science semata, melainkan ilmu amaliah tercakup di dalamnya.

c) Anak cenderung mengikuti apa yang dilihatnya dari orang dewasa oleh karena itu hendaknya orang-orang tua membiasakan berprilaku keseharian dengan akhlakul karimah, baik perkataan maupun perbuatan.

Pendidikan agama pada dunia pendidikan merupakan modal dasar bagi anak untuk mendapatkan nilai-nilai ketuhanan, bahwa betapa pentingnya nilai-nilai agama diajarkan kepada anak, dimana dalam dunia pendidikan dicakup dalam satu bidang garapan yaitu pendidikan agama. Pendidikan agama dalam kehidupan tidaklah sepenuhnya menjadi tanggung jawab guru di sekolah, melainkan juga orang tua sebagai contoh nyata dalam kehidupan anak. Bagaimana mungkin anak akan berkarakter baik, jika orang tuanya hidup dalam ketidakbaikan. Oleh karena itu pendidikan agama harus ditanamkan kepada anak dimanapun ia berada, baik formal maupun non formal.

Konsep pendidikan karakter sebenarnya telah ada sejak zaman Rasulullah SAW. Hal ini terbukti dari perintah Allah bahwa tugas pertama dan utama Rasulullah adalah sebagai penyempurna akhlak bagi umatnya. Pembahasan substansi makna dari karakter sama dengan konsep akhlak dalam Islam, keduanya membahas tentang perbuatan prilaku manusia. Al-Ghazali menjelaskan jika akhlak adalah suatu sikap yang mengakar dalam jiwa yang darinya lahir berbagai perbuatan dengan mudah dan gampang tanpa perlu adanya pemikiran dan pertimbangan. 
Suwito menyebutkan bahwa akhlak sering disebut juga ilmu tingkah laku atau perangai, karena dengan ilmu tersebut akan diperoleh pengetahuan tentang keutamaankeutamaan jiwa; bagaimana cara memperolehnya dan bagaiman membersihkan jiwa yang telah kotor. Sedangkan arti dari Karakter adalah nilai-nilai yang khas-baik (tahu nilai kebaikan, mau berbuat baik, nyata berkehidupan baik, dan berdampak baik terhadap lingkungan) yang terpateri dalam diri dan terejawantahkan dalam perilaku. Karakter secara koheren memancar dari hasil olah pikir, olah hati, olah raga, serta olah rasa dan karsa seseorang atau sekelompok orang (Suwito, 2014).

Akhlak atau karakter dalam Islam adalah sasaran utama dalam pendidikan. Hal ini dapat dilihat dari beberapa hadits nabi yang menjelaskan tentang keutamaan pendidikan akhlak salah satunya hadits berikut ini: “ajarilah anak-anakmu kebaikan, dan didiklah mereka”. Konsep pendidikan didalam Islam memandang bahwa manusia dilahirkan dengan membawa potensi lahiriah yaitu:1) potensi berbuat baik terhadap alam, 2) potensi berbuat kerusakan terhadap alam, 3) potensi ketuhanan yang memiliki fungsi-fungsi non fisik.

Ketiga potensi tersebut kemudian diserahkan kembali perkembangannya kepada manusia. Hal ini yang kemudian memunculkan konsep pendekatan yang menyeluruh dalam pendidikan Islam yaitu meliputi unsur pengetahuan, akhlak dan akidah. Lebih luas Ibnu Faris menjelaskan bahwa konsep pendidikan dalam Islam adalah membimbing seseorang dengan memperhatikan segala potensi paedagogik yang dimilikinya, melalui tahapan-tahapan yang sesuai, untuk didik jiwanya, akhlaknya, akalnya, fisiknya, agamanya, rasa sosial politiknya, ekonominya, keindahannya, dan semangat jihadnya (Mahmud, 2003 ). Hal ini memunculkan konsep pendidikan akhlak yang komprehensif, dimana tuntutan hakiki dari kehidupan manusia yang sebenarnya adalah keseimbangan hubungan antara manusia dengan tuhannya, hubungan manusia dengan sesamanya serta hubungan manusia dengan lingkungan disekitarnya.

Akhlak selalu menjadi sasaran utama dari proses pendidikan dalam Islam, karena akhlak dianggap sebagai dasar bagi keseimbangan kehidupan manusia yang menjadi penentu keberhasilan bagi potensi paedagogis yang lain. Prinsip akhlak terdiri dari empat hal yaitu:

1) Hikmah ialah situasi keadaan psikis dimana seseorang dapat membedakan antara hal yang benar dan yang salah. 
2) Syajaah (kebenaran) ialah keadaan psikis dimana seseorang melampiaskan atau menahan potensialitas aspek emosional dibawah kendali akal

3) Iffah (kesucian) ialah mengendalikan potensialitas selera atau keinginan dibawah kendali akal dan syariat

4) ' $a d l$ (keadilan) ialah situasi psikis yang mengatur tingkat emosi dan keinginan sesuai kebutuhan hikmah disaat melepas atau melampiaskannya (Ridha,2003).

Prinsip akhlak diatas menegaskan bahwa fitrah jiwa manusia terdiri dari potensi nafsu yang baik dan potensi nafsu yang buruk, tetapi melalui pendidikan diharapkan manusia dapat berlatih untuk mampu mengontrol kecenderungan perbuatannya kearah nafsu yang baik. Oleh karena itu Islam mengutamakan proses pendidikan sebagai agen pembentukan akhlak pada anak. Islam selalu memposisikan pembentukan akhlak atau karakter anak pada pilar utama tujuan pendidikan. Untuk mewujudkan pembentukan akhlak pada anak al Ghazali menawarkan sebuah konsep pendidikan yang bertujuan mendekatkan diri kepada Allah. Menurutnya mendekatkan diri kepada Allah merupakan tolak ukur kesempurnaan manusia, dan untuk menuju kesana ada jembatan yang disebut ilmu pengetahuan.

Ibn miskawaih menambahkan tidak ada materi yang spesfik untuk mengajarkan akhlak, tetapi materi dalam pendidikan akhlak dapat diimplementasikan ke dalam banyak ilmu asalkan tujuan utamanya adalah sebagai pengabdian kepada Tuhan. Pendapat diatas menggambarkan bahwa akhlak merupakan pilar utama dari tujuan pendidikan didalam Islam, hal ini senada dengan latar belakang perlunya diterapkan pendidikan karakter disekolah; untuk menciptakan bangsa yang besar, bermartabat dan disegani oleh dunia maka dibutuhkan good society yang dimulai dari pembangunan karakter (character building). Pembangunan karakter atau akhlak tersebut dapat dilakukan salah satunya melalui proses pendidikan disekolah dengan mengimplementasikan penanaman nilainilai akhlak dalam setiap materi pelajaran (Abidin, 1998).

\section{DISKUSI}

\section{A. Pendidikan Agama Islam Terintegrasi Sebagai Pembentuk Karakter Bangsa}


Uraian diatas menggambarkan bahwa pendidikan merupakan agen perubahan yang signifikan dalam pembentukan karakter anak, dan pendidikan agama Islam menjadi bagian yang penting dalam proses tersebut, tetapi yang menjadi persoalan selama ini adalah pendidikan agama Islam disekolah hanya diajarkan sebagai sebuah pengetahuan tanpa adanya pengaplikasian dalam kehidupan sehari-hari. Sehingga fungsi pendidikan agama Islam sebagai salah satu pembentukan akhlak mulia bagi siswa tidak tercapai dengan baik (Nasution,1995).

Pola pembelajaran terhadap materi PAI diatas sudah saatnya dirubah. Guru yang menjadi ujung tombak keberhasilan sebuah pembelajaran harus menyadari bahwa tanggung jawabnya terhadap keberhasilan pembelajaran PAI tidak hanya pada tataran kognitif saja. Tetapi tidak kalah penting adalah bagaimana memberikan kesadaran kepada siswa bahwa pendidikan agama adalah sebuah kebutuhan sehingga siswa mempunyai kesadaran yang tinggi untuk melaksanakan pengetahuan agama yang diperolehnya dalam kehidupan sehari-hari.

Disinilah dibutuhkan kreatifitas guru dalam menyampaikan pembelajaran, dimana pembelajaran PAI seharusnya tidak hanya diajarkan didalam kelas saja, tetapi bagaimana guru dapat memotivasi dan memfasilitasi pembelajaran agama diluar kelas melalui kegiatan-kegiatan yang bersifat keagamaan dan menciptakan lingkungan sekolah yang religius dan tidak terbatas oleh jam pelajaran saja serta terintegrasi dengan mata pelajaran lain. Media ajar pendidikan agama Islam juga harus bervariasi. Penggunaan teknologi, aplikasi, video pembelajaran berkualitas akan dapat mempengaruhi akhlak dan karakter peserta didik.

Tujuan utama dari Pembelajaran PAI adalah pembentukan kepribadian pada diri siswa yang tercermin dalam tingkah laku dan pola pikirnya dalam kehidupan seharihari, maka pembelajaran PAI tidak hanya menjadi tanggung jawab guru PAI seorang diri, tetapi dibutuhkan dukungan dari seluruh komunitas disekolah, masyarakat, dan lebih penting lagi adalah orang tua. Sekolah harus mampu mengkoordinir serta mengkomunikasikan pola pembelajaran PAI terhadap beberapa pihak yang telah disebutkan sebagai sebuah rangkaian komunitas yang saling mendukung dan menjaga demi terbentuknya siswa berakhlak dan berbudi pekerti luhur.

Keberhasilan pembelajaran PAI disekolah salah satunya juga ditentukan oleh penerapan metode pembelajaran yang tepat. Sejalan dengan hal ini Abdullah Nasih 
Ulwan memberikan konsep pendidikan inluentif dalam pendidikan akhlak anak yang terdiri dari 1) Pendidikan dengan keteladanan, 2) Pendidikan dengan adat kebiasaan, 3) Pendidikan dengan nasihat,4) pendidikan dengan memberikan perhatian, 5) pendidikan dengan memberikan hukuman (Ulwan, $\mathrm{tt}$ ).

Ibnu Shina dalam Risalah al-Siyâsah mensyaratkan profesionalitas guru ditentukan oleh kecerdasan, agamanya, akhlaknya, kharisma dan wibawanya. Oleh karena itu salah satu proses mendidik yang penting adalah keteladanan. Perilaku dan perangai guru adalah cermin pembelajaran yang berharga bagi peserta didik. Tokoh pendidikan Indonesia Ki Hajar Dewantara mengatakan bahwa guru selayaknya berprinsip "ing ngarso sung tulodo ing madyo mangun karso" (didepan memberi contoh, ditengah memberikan bimbingan dan dibelakang memberikan dorongan). Keteladanan inilah salah satu metode yang seharusnya diterapkan guru dalam pembelajaran PAI. Guru harus mampu menerapkan nilai-nilai agama dalam kehidupannya sebelum mengajarkan nilai-nilai agama tersebut kepada siswa. Karena ia akan menjadi model yang nyata bagi siswa. Pendidikan yang berhubungan dengan kepribadian atau akhlak tidak dapat diajarkan hanya dalam bentuk pengetahuan saja, tetapi perlu adanya pembiasaan dalam prilakunya sehari-hari. Setelah menjadi teladan yang baik, guru harus mendorong siswa untuk selalu berprilaku baik dalam kehidupan sehar-hari. Oleh karena itu selain menilai, guru juga menjadi pengawas terhadap prilaku siswa seharihari disekolah, dan disinilah pentingnya dukungan dari semua pihak.

Karena didalam metode pembiasaan siswa dilatih untuk mampu membiasakan diri berprilaku baik dimana saja, kapan saja dan dengan siapa saja. Proses belajar mengajar yang diharapkan didalam pendidikan akhlak adalah lebih kepada mendidik bukan mengajar. Mendidik berarti proses pembelajaran lebih diarahkan kepada bimbingan dan nasihat. Membimbing dan menasehati berarti mengarahkan peserta didik terhadap pembelajaran nilai-nilai sebagai tauladan dalam kehidupan nyata, jadi bukan sekedar menyampaikan yang bersifat pengetahuan saja. Mendidik dengan memberikan perhatian berarti senantiasa memperhatikan dan selalu mengikuti perkembangan anak pada prilaku sehari-harinya. Hal ini juga dapat dijadikan dasar evaluasi bagi guru bagi keberhasilan pembelajarannya. Karena hal yang terpenting dalam proses pemelajaran PAI adalah adanya perubahan prilaku yang baik dalam kehidupan sehari-harinya sebagai wujud dari aplikasi pengetahuan yang telah didapat. 
Bentuk apresiasi guru terhadap prestasi siswa adalah adanya umpa balik yang positif yaitu dengan memberikan ganjaran dan hukuman (reward-punishment). Ganjaran diberikan sebagai apresiasi guru terhadap prestasi siswa sedangkan hukuman diberikan jika siswa melanggar aturan yang telah ditentukan, tetapi hukuman disini bukan berarti dengan kekerasan atau merendahkan mental siswa, tetapi lebih kepada hukuman yang sifatnya mendidik. Metode reward dan punishment dibutuhkan dalam pembelajaran PAI dengan Tujuan agar anak selalu termotivasi untuk belajar. Pemberian pengetahuan tentang aqidah yang benar menjadi dasar yang paling utama dalam penanaman akhlak pada anak.

Disinilah pentingnya pembelajaran pendidikan agama Islam disekolah, karena pendidikan agama merupakan pondasi bagi pembelajaaran ilmu pengetahuan lain, yang akan menghantarkan terbentuknya anak yang berkepribadian, agamis dan berpengetahuan tinggi. Maka tepat jika dikatakan bahwa penerapan Pendidikan agama Islam disekolah adalah sebagai pilar pendidikan karakter yang utama. Pendidikan agama mengajarkan pentingnya penanaman akhlak yang dimulai dari kesadaran beragama pada anak. Ia mengajarkan aqidah sebagai dasar keagamaannya, mengajarkan al quran dan hadits sebagai pedoman hidupnya, mengajarkan fiqih sebagai rambu-rambu hokum dalam beribadah, mengajarkan sejarah Islam sebagai sebuah keteladan hidup, dan mengajarkan akhlak sebagai pedoman prilaku manusia apakah dalam kategori baik ataupun buruk.

\section{B. Hambatan Dalam Pembentukan Karakter.}

Sekolah sebagai wahana pembelajaran tak diragukan berperan besar dalam pengembangan karakter siswa. Sekolah telah mengantar anak-anak dan remaja dalam menyelesaikan tugas perkembangannya hingga memasuki masa dewasa dengan baik. Di sekolah ini otak, hati, dan badan anak di ditumbuh kembangkan agar lebih cerdas, peka dan sehat. Namun dalam pelaksanaan pendidikan karakter di sekolah, dalam pelaksanaan masih ditemukan beberapa permasalahan, dikarenakan perkembangan jaman anak sekarang jauh berbeda dengan anak-anak terdahulu. Berikut beberapa hambatan dalam membentuk karakter anak di sekolah diantaranya;

1. Pengaruh Televisi/Internet/Kemajuan teknologi yang disalahgunakan. 
2. Lingkungan Masyarakat, Pergaulan di masyarakat dengan teman-temannya dapat mempengaruhi akhlaknya Lingkungan sangat berpengaruh bagi perkembangan karakter anak.

3. Tidak sinkronnya pendidikan atau aturan di sekolah dan di rumah suatu aturan yang diterapkan disekolah harus diterapkan juga di rumah jika sebaliknya maka akan menghambat pada tujuan pembentukan karakter anak.

4. Peran guru belum dapat menjadi teladan atas nilai-nilai karakter yang dipilihnya. Permasalahan yang paling berat adalah peran guru untuk menjadi teladan dalam mewujudkan nilai-nilai karakter secara khusus sesuai dengan nilai karakter mata pelajaran dan nilai-nilai karakter umum di sekolah.

5. Sekolah belum dapat memilih nilai-nilai karakter yang sesuai dengan visinya.

6. Minimnya jam pelajaran pendidikan Agama Islam di Sekolah Umum, sehingga, pemahaman agama bagi siswa/siswi di sekolah umum sangat minim.

Hambatan-hambatan ini dapat teratasi dengan mengintegrasikan pendidikan agama Islam dengan pelajaran lain dan teknologi. Nilai-nilai Islam dapat diajarkan pada setiap mata pelajaran sehingga keterbatasan jam bukanlah merupakan suatu rintangan. Pemanfaatan teknologi informasi dapat menjadi solusi untuk memantau dan membimbing peserta didik secara kontinyu tanpa dibatasi oleh jarak dan waktu.

\section{KESIMPULAN}

Penanaman karakter pada anak sejak dini berarti ikut mempersiapkan generasi bangsa yang berkarakter, mereka adalah calon generasi bangsa yang diharapkan mampu memimpin bangsa dan menjadikan negara yang berperadaban, menjunjung tinggi nilainilai luhur bangsa dengan akhlak dan budi pekerti yang baik serta menjadi generasi yang berilmu pengetahuan tinggi dan menghiasi dirinya dengan iman dan taqwa. Oleh karena itu pembelajaran pendidikan agama Islam (PAI) di sekolah sebagai salah satu upaya pembentukan karakter siswa sangatlah penting. Pembentukan Karakter anak akan lebih baik jika muncul dari kesadaran keberagamaan yang tercermin dari segala perilaku kehidupan bangsa. Perilaku keagamaan akan dapat tumbuh dan berkembang jika pendidikan Agama Islam terintegrasi dengan semua mata pelajaran serta sains dan teknologi. Perpaduan pendidikan agama Islam dengan sains dan teknologi adalah sebuah keniscayaan, sebab agama bertugas untuk mengawal dan mengontrol dari dampak negatif teknologi itu sendiri. 
Indikator keberhasilan pendidikan Karakter adalah jika seseorang telah mengetahui sesuatu yang baik (knowing the good) (bersifat kognitif), kemudian mencintai yang baik (loving the good) (bersifat afektif), dan selanjutnya melakukan yang baik (acting the good) (bersifat psikomotorik) .

\section{DAFTAR PUSTAKA}

Hidayat, Komarudin. 1999. "Menentukan Kembali Struktur Keilmuan Islam(Pengantar)'”. Dalam Fuadudin dan Cik Hasan Bisri, (Ed), DinamikaPemikiran Islam di Perguruan Tinggi: Wacana tentang Pendidikan AgamaIslam. Jakarta: Logos.

Indrawati. 2009. Pembelajaran Terpadu di Sekolah Dasar. Jakarta: Pusat Pengembangan dan Pemberdayaan Pendidik dan Tenaga Kependidikan.

Ifham Choli, 2019. Pembentukan Karakter Melalui Pendidikan Agama Islam, Jurnal UIA Tahdzib, 2019

Joyoatmojo, Soetarno. 2011. Pembelajaran Efektif: Pembelajaran yang Membelajarkan. Surakarta: UNS Press.

Koentjaraningrat. 1993. Kebudayaan: Mentalitas dan Pembangunan. Jakarta:Penerbit Gramedia.

Mahmud, Ali Abdul Halim, 2003, Tarbiyah Khuluqiyah Pembinaan Diri Menurut Konsep Nabawi, Terj Afifudin, Solo, Media Insani.

Permendiknas No 22 Tahun, 2006. Standar Isi Untuk Satuan Pendidikan Tingkat Dasar Dan Menengah.

Ridla, Muhammad Jawwad, 2002. Tiga Aliran Utama Teori Pendidikan Islam Perspektif Sosiologis-Filosofis, Terj Mahmud Arif, Yogyakarta, Tiara Wacana Yogya Sudrajat, Ajat, 2011, Mengapa Pendidikan Karakter?, Jurnal Pendidikan Karakter, Vol. 1, No. 1.

Rusn, Abidin Ibnu, 1998.Pemikiran Al-Ghazali Tentang Pendidikan, Yogyakarta, Pustaka Pelajar. 
Suwito, 2004, Filsafat Pendidikan Akhlak Ibn Miskawaih, Yogyakarta, Belukar. Kebijakan Nasional Pembangunan Karakter Bangsa Tahun, 20102025

Turmudi, dkk, Islam, Sains dan Teknologi Menggagas Bangunan Keilmuan Fakultas Sains dan Teknologi Islami Masa Depan, (Malang: UIN Maliki Press, 2006),

Ulwan, Abdullah Nasih, Pedoman Pendidikan Anak Dalam Islam, Terj Sefullah Kamalie Dan Hery Noer Ali, Jilid 2, Semarang, Asy-Syifa. Tt

Undang-Undang No. 20 Tahun 2003, Tentang Sistem Pendidikan Nasional.

http://xnophi.blogspot.co.id/2013/03/analisis-pembelajaran-pai-dalam.html 